\title{
A NOÇÃO DE EMPREGABILIDADE NAS POLÍTICAS DE QUALIFICAÇÃO E EDUCAÇÃO PROFISSIONAL NO BRASIL NOS ANOS 1990
}

\author{
THE NOTION OF EMPLOYABILITY IN THE POLICIES FOR PROFESSIONAL TRAINING \\ AND PROFESSIONAL EDUCATION IN BRAZIL IN THE 1990'S
}

Maria Angélica Alberto 1

Resumo O objetivo principal deste artigo é mostrar os sentidos que a noção de empregabilidade assumiu na concepção e no desenvolvimento das políticas de formação da força de trabalho no Brasil na década de 1990, processo este marcado pelas influências do pensamento neoliberal. Para isso, debruçou-se, basicamente, no exame de documentos produzidos pelos Ministérios da Educação, do Trabalho e Emprego e da Saúde, particularmente os que tratavam das políticas educacionais e de formação, bem como aqueles que se referiam à execução de tais políticas. Conclui-se que o campo educacional, particularme nte quando nas mãos dos Ministérios da Educação e do Trabalho e Emprego, constituiu-se em um dos principais veículos de divulgação da noção de empre gabilidade e que a utilização desta noção condicionou padrões de pensamento e comportamento tanto nos processos educacionais como nas relações de trabalho. O Ministério da Saúde utilizou a noção de empre gabilidade política de mão-de-obra à froid, na tentativa de minimizar os impactos da falta de qualificação da força de trabalho na área da saúde.

Palavras-chave empregabilidade; mercado de trabalho; formação profissional; educação profissional.
Abstract This article's main objective is to present the different meanings that the term employability has acquired both at the conception and throughout the development of training policies for the work force in Brazil in the 1990's, a process which was highly influenced by neoliberal thinking. In order to do so, we minutely examined various documents produced by the Ministry of Education, the Ministry of Labor and Employment and the Ministry of Health, particularly those documents that touched upon education and training policies and the implementation of such policies. The conclusion is that education, particularly while administered by the Ministry of Education and the Ministry of Labor and Employ ment, was one of the major means through which the notion of employability was disseminated. Another conclusion is that the use of this notion has conditioned thinking and behavior in educational processes and labor relations. The Ministry of Health also applied the notion of political employability of wo rke rs in the attempt of minimizing the impact of the lack of qualification of the work force in the area of health.

Key words employability; job market; professional training; professional education. 


\section{Introdução}

A noção de empregabilidade surgiu em 1900, na Grã-Bretanha. A primeira ve rsão de empre gabilidade, denominada 'empre gabilidade dicotômica', foi uma interpretação classificatória e simples que persistiu, sobretudo no Reino Unido e nos Estados Unidos, até o início da década de 1950. Posteriormente, na mesma década, nos Estados Unidos, uma nova versão da noção foi identificada nos trabalhos de origem médica e médico-social e chamada de 'empregabilidade médico-social'.

Se, em um prime i ro mome nto, ela serviu para classificar aqueles que poderiam ou não ser absorvidos pelo mercado de trabalho, em um segundo momento, a noção passou a ter um uso médico que procurou estabelecer tipos de empre gabilidade segundo a gravidade do dano físico ou psíquico apresentado. Nos dois casos, o papel do Estado seria fundamental na promoção de ações ou programas que possibilitassem a inserção ou, simplesmente, a tomada para si da responsabilidade de sobrevivência dos considerados 'in-empregáveis'.

Mas foi a partir dos anos 60 - quando o governo americano começou a desenvolver ações focalizadas em grupos de mão-de-obra em posição desfavorável no mercado de trabalho, com o objetivo de melhorar a formação de pessoas em dificuldades - que se percebeu o surgimento de uma nova versão de empre gabilidade, denominada 'empre gabilidade política de mão-deobra'. Compreende-se, deste modo, que esta noção de empregabilidade teve sua origem nas discussões, ocorridas, principalmente, nos Estados Unidos, sobre os caminhos que deveriam seguir as ações que tinham como meta o aumento da empre gabilidade dos grupos socialmente desfavorecidos ou desempregados em dificuldades.

A França foi palco do aparecimento de uma outra ve rsão da noção de empregabilidade, esta com uma conotação puramente estatística, denominada 'empregabilidade-fluxo'. Ela se originou a partir da dificuldade de reclassificação de grupos de desemprega dos, e sua utilização foi puramente de recenseamento e análise de dados.

Posteriormente, no final da década de 1970, a versão que predominou foi a de 'empregabilidade performance sobre o mercado de trabalho'. Esta versão teve origem em trabalhos americanos que propunham uma definição estatística mais neutra e completa da noção de empre gabilidade. Seu uso possibilitou que fossem feitas avaliações retrospectivas de programas de intervenção.

No início dos anos 90, surgiram duas novas versões da noção de empregabilidade, em torno das quais, pelo menos na Europa, o debate hoje se concentra: a 'empregabilidade-iniciativa' e a 'empregabilidade-interativa'. A gênese destes dois significados só pode ser compreendida quando se leva em conta o novo cenário que começou a ser desenhado já a partir da década de 
1980, mas que atingiu seu ápice na década seguinte. Trata-se da reestruturação produtiva que impôs uma nova dinâmica ao mercado de trabalho, bem como o recrudescimento do desemprego estrutural e a erosão de um modelo de emprego alicerçado em carreiras.

Gazier (2001) afirma que a empre gabilidade-iniciativa pode ser entendida como aquela que insiste sobre a responsabilidade individual e sobre a c apacidade de uma pessoa para mobilizar, em torno de seus projetos, um processo de acumulação de 'capital' humano e de 'capital' social.

Para o autor, esta versão pode ser definida pela negociação de competências individuais acumuladas e medida pela ampliação do capital humano acumulado e suscetível de o ser (conhecimentos e atitudes produtiva s, mais capacidades de aprendizagem) e pelo modo como uma pessoa é c apaz de mobilizar em torno dela uma rede de colaborações e apoios (Gazier, 2001).

Para Gazier, a utilização desta ve rsão tem conseqüências em termos de políticas a se desenvolver, que seriam, então, a promoção da ap rendizagem ao longo da vida, o aperfeiçoamento de informações sobre o mercado de trabalho e sua flexibilização.

Levando em conta estas gêneses da noção de empre gabilidade é que se considera importante mostrar como esta noção se fez presente nas políticas de formação da força de trabalho no Brasil.

Desta forma, o objetivo do presente artigo é ap resentar as versões da noção de empre gabilidade utilizadas nos anos 90, principalmente nos disc u rsos produzidos pelas instituiçõesresponsáveis pelas políticas de formação da força de trabalho e de geração de emprego e renda no Brasil. A ênfase foi dada aos ministérios da Educação (MEC) e do Trabalho e Emprego (MTE), por se considerar que foram exatamente estes dois ministérios os que estiveram mais envolvidos nas propostas e políticas de formação da força de trabalho.Contudo, o Ministério da Saúde (MS) também foi incorporado à análise, em razão de suas ações de qualificação da força de trabalho da á rea da saúde através do Programa de Profissionalização dos Trabalhadores da Área de Enfermagem (Profae).

\section{A pesquisa}

A pesquisa foi desenvolvida com material documental. Quanto ao MEC, foram analisados leis, decretos, pareceres, resoluções e portarias, produzidos e publicados pelo Conselho Nacional de Educação (CNE) e MEC a partir de 1996, ano em que a Nova Lei de Diretrizes e Bases da Educação(LDB) foi sancionada; documentos do Programa de Expansão da Educação Profissional (Proep), assim como projetos selecionados por este programa para fins de fi- 
nanciamento, quais sejam os Planos Estaduais de Educação Profissional (PEP) e os Planos Estratégicos Escolares (PEC); e documentos do Programa Técnico-Empreendedor.

Do MTE, foram utilizados cinco documentos da série Avanço conceitual, além de cinco outros documentos que continham exemplos de como a noção de empre gabilidade permeou as políticas públicas de trabalho, empre go e renda, desenvolvidas a partir de 1996 pelo MTE.

Em relação ao MS, consideraram-se: a revista Formação, publicação periódica que divulga artigos técnicos e informativos do Profae; a obra intitulada Pro fae: educação profissional em saúde e cidadania, onde estão re u n idos vários artigos avaliativos do projeto; e o Relatório Geral do Prime i ro Fórum Nacional do Profae.

\section{A noção de empregabilidade nas orientações de política educacional do Ministério da Educação}

De um ponto de vista geral, conforme apresentado anteriormente, a reconstituição histórica do termo empregabilidade remonta a década de 1900. Ao longo do tempo, o termo assumiu vários sentidos. No Brasil, entretanto, o aparecimento desta noção data dos anos 90, exatamente quando ocorreu o recrudescimento da insegurança no trabalho, que levou à adoção deste termo e de outras proposituras e posturas em relação à força de trabalho.

A investigação realizada permitiu que se detectasse nos documentos do MEC, que tratavam da política de formação e qualificação, o predomínio de duas versões da noção de empregabilidade. Segundo a classificação de Gazier (2001), trata-se da empregabilidade-iniciativa e da empregabilidade política de mão-de-obra.

O sentido da empregabilidade-iniciativase nota já no artigo 35 da LDB, de 1996, que trata das finalidades do ensino médio. Tal artigo estabelece que uma das finalidades deste nível de ensino seria “a preparação básica para o trabalho e a cidadania do educando, para continuar aprendendo, de modo a ser capaz de se adaptar com flexibilidade 2 a novas condições de ocupação ou aperfeiçoamentos posteriores" (MEC, 2001a, p. 30).

A valorização do aprendizado contínuo também se fez presente na resolução n 3 de 26 de junho de 1998 da Câmara de Educação Básica (CEB) do CNE, que instituiu as Diretrizes Curriculares para o Ensino Médio, determinando ser uma de suas finalidades promover o "desenvolvimento da capacidade de aprender e continuar aprendendo" (MEC, 1998).

A leitura de documentos do Proep também permitiu que se identificasse a noção classificada como empre gabilidade-iniciativa Em um projeto escolar do segmento federal, por exemplo, a idéia veiculada é que "o progr a- 
ma de educação profissional (...) busca contemplar o mercado de trabalho sob a ótica da 'empregabilidade' e da 'educação continuada"' (PEP-RJ).

Em outro projeto escolar, menciona-se que

“(...) um dos aspectos mais dramáticos da transformação da economia industrial para a economia do conhecimento é a velocidade com que as mudanças se processam e que o único caminho para os trabalhadoresda sociedade do conhecimento manterem suas qualificações e atuarem como capital humano é se comprometendo com um ap rendizado contínu o, o que afetará todos os trabalhadores, tanto como indivíduos quanto como empregados ou empregadores" (PEP-AM).

Na Europa, a questão relativa à educação e formação ao longo da vida passou a ser uma orientação da Comissão Européia a partir de 1996. Esta comissão, inclusive, consagrou esse ano à educação, denominando-o Année européenne de l'éducation et la formation tout au long de la vie. No Brasil, a idéia passa a ser disseminada no mesmo período. Tanto nos países de capitalismo avançado quanto nos de capitalismo periférico, como o Brasil, a idéia toma corpo em um momento em que o desemprego estrutural sofre elevações contínuas.

A noção de empregabilidade-iniciativa refere-se à necessidade do desenvolvimento de um processo de acumulação de capital humano, através da educação, da educação continuada e do ap rendizado ao longo da vida. Ta nto a LDB como a resolução $\mathrm{n}^{\circ} 3$ da CEB-CNE e um núme ro significativo dos projetos escolares financiados pelo Proep enfatizam a necessidade do contínuo ap rendizado, do retorno constante à escola e da aprendizagem ao longo da vida, entendendo que estes processos possibilitariam a adaptação flex ível às novas condições de ocupação.

Face ao contexto da reestruturação produtiva do capitalismo, surgem implicações para as instituições escolares. Em vários dos documentos consultados, aparece a atribuição de responsabilidade à escola pela baixa qualificação da população economicamente ativa (PEA) e, por causa disso, pelo estrangulamento do crescimento econômico, daí a necessidade da formação contínua.

Machado (1998) registra que, neste período histórico, a educação pass a a ser submetida a um questionamento bipolar: por um lado, é vista como a responsável pelo atraso e pobreza; por outro, como a via da promoção e elevação dos padrões de qualidade de vida.

Este também é o momento histórico de ampliação do conceito de educação básica, levando a novas referências curriculares. Estas deveriam "contemplar a necessidade de dotar o trabalhador de perfil amplo, generalista e pro mover sua iniciação à cultura específica do novo paradigma tecnológico" (Machado, 1998, p. 17).

Ao mesmo tempo em que estas idéias são veiculadas, a realidade evid e ncia o aumento sem precedentes do desemprego estrutural, que atinge tanto 
as pessoas de baixa escolaridade como as portadoras de alto nível educacional. Dados do MTE mostram que, entre 1990 e 1998, houve uma redução dos postos de trabalho qualificados na ordem de 12,3\% no Brasil, enquanto as ocupações não-qualificadas cresceram em 14,2\% (Pochmann, 2000).

Ao lado da formação e educação ao longo da vida, arg umenta-se que políticas públicas de geração de emprego e renda deveriam ser desenvolvidas, pois esta seria uma das formas de fazer com que o valor agre gado à força de trabalho através da educação pudesse se transformar em valor de troca. A questão que se coloca é que estas políticas não são viabilizadas, daí a impossibilidade de concretização do valor de troca.

A noção de empre gabilidade é usada com a premissa de que os indivíduos devem acreditar que o reiterado retorno à escola seria a garantia de sua inserção e permanência no mundo do trabalho. Os documentos sobre as orientações de políticas educacionais produzidos na esfera da educação buscam gerar a mesmaex pectativa nos indivíduos. A idéia é que a educação geraria a segurança no trabalho.

No decreto federal $n^{\circ} 2.208$ de 17 de abril de 1997 - queregulamenta o parágrafo $2^{\circ}$ do artigo 36 e os artigos 39 a 42 da lei federal $n^{\circ} 9.934$ de 1996 -, em seu item IV, artigo 1, que trata dos objetivos da educação profissional, encontraram-se também elementos considerados comuns ao discurso da empregabilidade-iniciativa. Diz o decreto que a qualificação, reprofissionalização e atualização de jovens e adultos trabalhadores teriam como objetivo inserir e melhor preparar para o desempenho no exercício do trabalho.

A educação profissional, à luz da reestruturação produtiva, passa a ser investida de novas funções voltadas para a formação de um trabalhador com um novo perfil. Assim, qualificar, requalificar, atualizar e reprofissionalizar passam a ser considerados objetivos fundamentais, uma vez que o que se ap rende não é o suficiente para sempre. Como a realidade está em constante mutação, necessário se faz que se esteja permanentemente em busca de novos conhecimentos para solucionar novos problemas.Daí a importância do ap rendizado diário, possibilitando que novas necessidades sejam superadas e que outras surjam desafiando a busca por novas respostas.

Os elementos comuns à noção de empre gabilidade-iniciativa, qual seja o processo de acumulação de capital humano através da formação contínua (qualificação, atualização, re profissionalização) como capaz de possibilitar o dinamismo profissional, inspiram a elaboração deste decreto e a re forma da educação profissional.

Sem colocar sob suspeita o direito de acesso à educação, o que, aliás, continua sendo, como avalia Machado (1998, p. 17), "uma dívida social cujo resgate já há muito deveria ter sido pago", sabe-se que a educação, por si só, não é capaz de resolver as incoerências e os desequilíbrios do mercado de trabalho. Sabe-se que políticas educacionais não têm o poder de gerar em- 
pregos, nem podem ser pensadas fora do contexto de políticas econômicas e sociais mais amplas. No entanto, essas teses são defendidas nas discussões sobre empre gabilidade presentes nas orientações de política educacional dos anos 90 .

Outros elementos comuns à noção de empre gabilidade-iniciativa puderam ser percebidos nos documentos que tratavam da educação profissional. É o caso, por exemplo, do termo 'flexibilidade' e da 'construção de itinerários profissionais ao longo da vida produtiva'.

No parecer $n^{\circ} 16$ da Câmara de Educação Básica do CNE, de 5 de outubro de 1999, que trata das Diretrizes Curriculares Nacionais para a Educação Profissional de Nível Técnico, estas ex p ressões ou idéias que se fazem presentes na noção de empregabilidade-iniciativa foram encontradas.

$\mathrm{O}$ item $\mathrm{n}^{\circ} 6$ do parecer em questão, que trata dos Princípios da Educação Profissional, explicita que as diretrizes regem-se por um conjunto de princípios que se referem a valores estéticos, políticos e éticos. Existiriam também, segundo o parecer, outros princípios que definem a identidade e especificidade deste nível de ensino, dizendo respeito "ao desenvolvimento de competências para a laborabilidade, à flexibilidade" (MEC, 2001c, p. 116-117).

É o caso, também, de outro item deste parecer, que preconiza o seguinte: “Torna-se cada vez mais essencial que o técnico tenha um perfil de qualificação que lhe permita construir itinerários profissionais, com mobilidade, ao longo da vida produtiva" (p. 113).

Também na resolução $\mathrm{n}^{\circ} 3$ da CEB, de 1998, que discute as diretrizes curriculares para o ensino médio, podem ser identificadas idéias encontradas na definição da empregabilidade-iniciativa Isso se verifica na enu nciação das finalidades do ensino médio, que seriam promover a autonomia intelectual e o pensamento crítico, capacitando o indivíduo a prosseguir os estudos e a adaptar-se com flexibilidade a novas condições de ocupação ou aperfeiçoamento. O domínio dos princípios e fundamentos científico-tecnológicos que presidem a produção moderna de bens, serviços e conhecimentos, tanto em seus produtos como em seus processos, o capacitaria a relacionar a teoria com a prática e a desenvolver a "flexibilidade para novas condições de ocupação ou aperfeiçoamento posteriores" (MEC, 1998).

$\mathrm{Na}$ LDB, a idéia de flexibilidade se faz presente mais especificamente no artigo 35, no entendimento de que a preparação básica para o trabalho e a cidadania do educando possibilitaria a adaptação flexí vel às novas condições de ocupação ou aperfeiçoamento posteriores.

Nos projetos escolares financiados pelo Proe p, selecionados para este estudo, muitas são as re ferências à educação para a flexibilidade, no sentido de capacidade de trabalhar as diversidades, de fazer frente às mudanças.

Na classificação de Gazier (2001), a questão da flexibilidade no trabalho e do trabalho está direta mente implicada na noção de empregabilidade- 
iniciativa, pois ser flexível é poder transitar com segurança e autonomia em várias situações de trabalho ou ocupação. Nesta perspectiva, pode-se considerar que, para que um indivíduo seja considerado alguém dotado de empregabilidade, é necessário que ele tenha flexibilidade, ou seja, que ele possa atuar em situações novas, imprevistas e inusitadas, que ele seja capaz de trabalhar as diversidades com as quais se depare e que tenha flexibilidade frente às mudanças. Esta flexibilidade seria obtida através da educação continuada, da formação ao longo da vida, que possibilitaria, também, a construção de vários itinerários profissionais.

É indiscutível a idéia da necessidade do ap rendizado contínu o, da educação continuada, pois o que se tem de permanente é a contínua mudança da realidade em que se vive. $\mathrm{O}$ homem sempre terá novas necessidades a suprir e é exatamente na busca de atender a estas necessidades que ele produzirá novos conhecimentos. Assim, o processo de produção do conhecimento passa a ser entendido como um processo inacabado, por meio do qual o homem constrói sua própria existência.

Entretanto, o processo de mundialização do capital tem imposto uma lógica de exclusão que tende a limitar a integração dos indivíduos à vida produtiva Neste contex to, a tese que advoga o poder do ap rendizado contínuo e do aperfeiçoamento constante na construção da empregabilidade, tendo em vista a adaptação flexível, escamoteia a realidade, pois é crescente o número de pessoas tituladas que se encontram desempregadas.

As orientações para a política educacional, produzidas no campo governamental responsável pela educação nacional, também incidiram no desvio de colocar sobre os ombros do indivíduo a responsabilidade pela sua inserção e permanência no mercado de trabalho, pelo seu sucesso ou fracasso na geração de sua própria renda. Este desvio ou inve rsão ex i me o sistema econômico, particularmente a lógica excludente do capital, da responsabilidade pelo desemprego, culpabilizando o indivíduo por sua incapacidade de transformar sua força de trabalho em valor de uso, mesmo depois de ter tido possibilidade de agregar mais valor a ela mediante o acesso à educação.

A questão da flexibilização e construção de itinerários profissionais pode ser relacionada a uma das formas de insegurança no trabalho que Matoso (1998) chama de insegurança na contratação. Segundo o autor, observa-se, hoje, o aumento da contratação descentralizada e a ampliação das formas de contrato por tempo determinado e contrato para tempo parcial e, até me smo, relações de trabalho sem contrato.

Há que se perguntar sobre os efeitos psicológicos desta constante tensão a que fica submetida a força de trabalho, que não tem idéia de como será seu amanhã, se encontrará quem se interesse por comprar sua força de trabalho e se os ingredientes que deverão ser agre gados a ela, para que continue a ser atrativa, estarão disponíveis. 
Sennett (2004) faz uma discussão interessante sobre flexibilidade versus caráter, avaliando que o aspecto da flexibilidade que mais causa confusão é seu impacto sobre o caráter. Para ele, este termo

“(...) concentra-se sobretudo no aspecto a longo prazo de nossa experiência emocional. É expresso pela lealdade e o compromisso mútuo, pela busca de metas a longo prazo, ou pela prática de adiar a satisfação em troca de um fim futuro (...). Caráter são os traços pessoais a que damos valor em nós mesmos, e pelos quais buscamos que os outros nos valorizem. (...) Como decidimos o que tem valor duradouro em nós numa sociedade impaciente, que se concentra no momento imediato? Como se pode manter lealdade e compromissos mútuos em instituições que vivem se desfazendo ou sendo continu a mente retro p rojetadas? Estas são as questões sobre o caráter impostas pelo novo capitalismo flexível" (Sennett, 2004, p. 10).

A insegurança e a incerteza estão entremeadas nas práticas cotidianas Elas seriam, na ve rdade, as responsáveis pela difusão e aceitação das idéias de adaptação flexível e de construção de múltiplos itinerários profissionais. Alguns gestores de recursos humanos propõem até mesmo que os contratos sejam feitos por projetos, o que possibilita, sem dúvida, a construção de vários itinerários profissionais, trazendo, entretanto, a dificuldade de se prever minimamente o amanhã.

No parecer $n^{\circ} 16$ da CEB-CNE, estão presentes termos que podem ser vistos como equivalentes à noção de empregabilidade, mais especificamente no sentido atribuído por Gazier (2001) à empregabilidade-iniciativa.Éo caso do termo 'laborabilidade', que, neste pare cer, é entendido como a capacidade de "aprender os sinais de reviravolta dos padrões de qualidade e, inclusive, intuir sua direção" (MEC, 2001c, p.119). Na compreensão deste parecer,

“O desenvolvimento de competências profissionais deve proporcionar condições de laboralidade, de forma que o trabalhador possa manter-se em atividade produtiva e geradora de renda em contextos socioeconômicos cambiantes e instáveis" (MEC, 2001c, p.126).

Quando, neste tex to, fala-se de outro valor, a 'política da igualdade', o termo laboralidade é nova mente colocado em pauta. Diz o documento que, se a educação profissional "for eficaz para aumentar a laboralidade contribui para a inserção bem-sucedida no mercado de trabalho, ainda que não tenha poder, por si só, para gerar emprego" (MEC, 2001c, p. 121).

Dos projetos que integram o Proep, o termo laboralidade é evocado apenas em alguns, que, neste caso, se re fe rem ao segmento estadual. Pode-se, assim, mencionar os PEP dos estados do Maranhão, Pará e Alagoas, que consideram que a educação profissional deve ter como perspectivao desenvol- 
vimento de competências voltadas para a laboralidade, visando garantir maiores oportunidades de aquisição desta.

Existem pontos comuns entre as noções de empregabilidade e de laboralidade, principalmente o viés otimista e a orientação individualizante, que não levam em conta as forças discriminatórias e a seletividade do mercado.

O valor a ser agre gado à força de trabalho, em última instância, não é uma escolha pessoal, mas uma prerrogativa do me rcado. Esta é a razão pela qual Gazier (2001) lembra que o aperfeiçoamento de informações sobre o mercado é um dos aspectos a serem considerados nas políticas que se desenvolvem com base na empregabilidade-iniciativa Este conhecimento serviria tanto para orientar o planejamento de novas ofertas educacionais como para saber quais as novas competências que estão sendo requeridas pelo merc ado em determinado momento.

De maneira geral, entende-se serem estes os pontos que fazem com que os discursos da empregabilidade-iniciativa e da laboralidade sejam considerados um só discurso.

Entretanto,um aspecto que os dife rencia é a problemática do empre go. Na discussão sobre empregabilidade, de forma geral, está implícita ou explicitamente posta a disponibilidade de empregos - a carência seria de pessoas com perfis profissionais adequados. Já na discussão sobre laboralidade, remete-se simplesmente ao tema mais amplo da atividade do trabalho, sem compromissos com o questionamento da falta de empregos.

Apesar das diferenças sutis, ambas as noções surgem, curiosamente, em um contexto no qual o processo produtivo cada vez menos necessita da força de trabalho para produzir. Em comum, há a ênfase na suposição de que a educação teria o poder de aliviar os sujeitos da aflição do desemprego ou da falta de trabalho. Ambas têm em comum, também, a tendência de deixar incólumes a estrutura social e a dinâmica seletiva e concentradora da produção capitalista, para atribuir a responsabilidade aos indivíduos em particular.

Um outro termo também se faz presente nos documentos do MEC que foram consultados. Trata-se da noção de empreendedorismo, que pode ser considerado correspondente à noção de empre gabilidade, mais especificamente nas formulações caracterizadas como empregabilidade-iniciativa.

Foram encontradas várias definições do que seria empreendedor/emp reendedorismo em textos que tratam deste assunto. Dolabela (1999) diz que ser empreendedor não seria somente uma questão de acúmulo de conhecimentos, mas, principalmente, a assimilação de valore s, atitudes comportamentais e formas de percepção do mundo e de si mesmo, voltadas para atividades em que o risco, a a capacidade de inovar, preservar e conviver com a incerteza seriam elementos fundamentais. O empreendedor seria alguém que acredita poder colocar a sorte a seu favor, por entender que ela é fruto do trabalho duro. 
O entendimento sobre empreendedorismo, na perspectiva do autor citado, encontra-se subjacente à noção classificada por Gazier (2001) como empregabilidade-iniciativa. Para este autor, é o aspecto dinâmico desta versão que a faz interessante, pois ela privilegia as características individuais que estão próximas de um modelo empresarial. Desta forma, a pessoa mais empregável seria aquela que pudesse obter renda de seus conhecimentos e de suas redes de relações, ou seja, a pessoa mais empregável é aquela que cria trabalho.

Os documentos do MEC selecionados para este estudo que se referem ao empreendedorismo tratam da preocupação com o desenvolvimento das características mencionadas por Gazier e argumentam que o desenvolvimento destas estaria sob a responsabilidade da educação profissional.

No parecer $\mathrm{n}^{\circ} 16$ da CEB-CNE, o termo empreendedorismo aparece com o significado de espírito de risco e iniciativa para gerenciar o próprio percurso no mercado de trabalho.

Referências a esta idéia constituem o núcleo central do Programa Técnico-Empreendedor, desenvolvido pelo MEC por intermédio da Secretaria de Educação Média e Tecnológica (Semtec) em parceria com o Serviço Brasileiro de Apoio à Micro e Pequena Empresa (Sebrae). Segundo o MEC (2002), o programa converge para o atendimento de um objetivo comum entre as duas instituições, que são a "disseminação da cultura empreendedora", bem como o fortalecimento das características comportamentais empreendedoras e o estímulo e desenvolvimento das habilidades de gerenciamento de negócios do empreendedor, de forma a propiciar aos indivíduos competitividade e permanência no mercado.

O termo empreendedorismo também foi amplamente citado nos proj etos dos segmentos federal, estadual e comunitário selecionados pelo Pro ep. Um núme ro significativo deles atribuiu à educação profissional a responsabilidade pelo desenvolvimento do empreendedorismo, sob o arg u mento de que esta seria a grande resposta para um mundo no qual o emprego formal diminui cada vez mais.

Esta ênfase se expressa em passagens de diversos documentos, originados de várias unidades federativas. Trata-se de formulações como: "fomento à formação empreendedora e incre mento para a educação multifuncional" (PEP-BA); "a perspectiva empreendedora deve ser levada em conta, pois em um mundo altamente competitivo, sairão na frente aqueles que têm capacidade de trabalhar as dive rsidades"; "desenvolvi mento de competências voltadas para o empreendedorismo" (PEP-ES); “promoção da Educação Profissional, em todos os níveis e modalidades de ensino, formando profissionais qualificados para o mundo do trabalho e para o exercício da cidadania, numa perspectiva (...) do empreendedorismo" (PEP-PA); “promoção da formação do cidadão-profissional empreendedor" (PEP-MG); "necessidade de se ofertar cursos que estimulem a livre iniciativa e o empreendedorismo 
nos futuros profissionais, no sentido de criar novos postos de trabalho, organizar novas empresas etc." (PEP-RR); "promoção de EP [educação profissional] que possibilite o desenvolvimento do empreendedorismo" (PEPGO); “desenvolvimento de competências relacionais, atitudinais e tecnológicas, de modo a assegurar o estímulo ao empreendedorismo" (PEP-AP); “EP proporcionando condições de (...) empreendedorismo" (PEP-RO); “qualificar (...) para o trabalho com vínculo empregatício ou como empreendedor (...) e busca da cultura do empreendedorismo" (PEP-TO); e "qualificação que possibilite às pessoas trabalharem como autônomas (...) desenvolvimento da capacidade empreendedora" (PEP-AC).

O tema do empreendedorismo tornou-se, nos últimos anos, um assunto de interesse ${ }^{3}$. O comportamento empreendedor passou a ser considerado um dos principais fatores do desenvolvi mento econômico de um país. O prérequisito para a atividade empreendedora seria a existência de um conjunto de valores sociais e culturais que poderiam encorajar a criação de novas empresas. Au t o res como Dolabela (1999) alertam para a necessidade de uma educação que priorize va l o res como autonomia, independência, capacidade de gerar o próprio empre go, de inovar e gerar riquezas e capacidade de assumir riscos e crescer em ambientes instáve i s. Seriam estes os va lo res sociais c apazes de conduzir os países ao desenvolvimento.

Atribui-se, assim, uma enorme importância à formação que desenvolva a iniciativa e a criatividade, que gere consciências capazes de construir, agir e empreender. O que se encontra subjacente a estas formulações, contudo, é a intenção de que é preciso desresponsabilizar o Estado pela criação de políticas de geração de emprego e renda, para colocar nos ombros dos indivíduos a responsabilidade por sua inserção no mercado de trabalho. Trata-se aqui, também, tal como no discurso da empre gabilidade, da intenção de orientar e educar os indivíduos segundo novas regras de conduta e comportamento.

Como se disse anteriormente, no caso brasileiro foi possível constatar a presença importante, na documentação analisada, da noção classificada por Gazier (2001) como empre gabilidade política de mão-de-obra. Esta se volta para medir a distância entre as características de um indivíduo e os atributos exigidos pela produção, ou seja, para a aceitabilidade pelo mercado de trabalho. Neste sentido, ações poderiam ser desenvolvidas para suprir deficiências que estivessem impossibilitando o acesso do indivíduo a este me rcado, tais como programas de formação profissional.

Na leitura dos projetos dos segmentos federal e estadual que vêm sendo desenvolvidos com o apoio do Proep, foram detectadas idéias que traduzem este sentido da noção de empre gabilidade, designada como política de mão de-obra. Tais projetos se propõem a ofertar educação profissional básica para um segmento da população carente de escolaridade, que teria, segundo os proponentes, maiores dificuldades de inserção ocupacional. A educação 
passa a ser explicitamente responsabilizada pelo desenvolvimento da empregabilidade e, conseqüentemente, da inserção profissional.

Os projetos foram concebidos pelos gestores da educação com a convicção de que a qualificação profissional visa à redução contínua do grande contingente de desempre gados (PEP-ES); que a educação profissional desenvolvida em articulação com os dive rsos organismos sociais viabilizaria a inclusão social de jovens e adultos que se encontram excluídos por não terem escolaridade adequada às exigências do mercado (PEP-PA); que progr amas de educação básica e qualificação específica contribuiriam para o aumento da empregabilidade dos trabalhadores (PEP-AL); e que as políticas de educação profissional assegurariam o acesso ao conhecimento das tendências tecnológicas aos sem trabalho, aos profissionais desempre gados e aos sem qualificação, possibilitando-lhes a inclusão social (PEP-RS).

Nota-se a preocupação em atender, por meio da educação profissional, aos que estão sendo ou podem vir a ser excluídos do mercado. Assim, pretende-se, com o desenvolvimento de programas de educação básica, diminuir a distância entre os indivíduos e o mercado de trabalho. É ex a ta mente esta a idéia que constitui o sentido da empregabilidade política de mão-de-obra.

$\mathrm{Na}$ grande maioria dos documentos analisados referentes a projetos que têm sido financiados pelo Proep, atribui-se à educação profissional objeti vos como: garantir um bom nível de empre gabilidade; buscar melhores condições de conhecimento e empre gabilidade; promover a formação de p rofissionais numa perspectiva da empre gabilidade; buscar contemplar o mercado de trabalho sob a ótica da empre gabilidade; promover a oferta de c u rsos e serviços que possibilitem a empregabilidade; desenvolver competências relacionais, atitudinais e tecnológicas, de modo a assegurar as condições de empregabilidade dos educandos; proporcionar condições de empregabilidade; contribuir para a manutenção da empregabilidade; ter como foco a empre gabilidade do egresso; formar para a empre gabilidade; e criar condições efetivas de empregabilidade.

Apesar de se referirem profusamente a esta noção, não foram encontradas definições sobre o que designaria especificamente o termo empregabilidade. Apenas em três dos projetos consultados percebeu-se esta preocupação.

O PEP do estado do Piauí, por exemplo, diz que:

\footnotetext{
“A formação profissional propiciada tem como objetivo a empregabilidade, entendida como capacidade de se obter um emprego e manter-se no mercado de trabalho em constante mutação, bem como o empreendedorismo, entendido como a capacidade de montar e gerir um empreendimento próprio" (PEP-PI).
}

Já no PEP do Espírito Santo: 
“(...) empre gabilidade é um novo conceito de inserção no mercado de trabalho. Pode ser definida como um conjunto de competências, habilidades, valores e atitudes que permitem ao profissional obter sucesso na busca por um empre go ou por uma função produtiva" (PEP-ES).

O PEP do Rio Grande do Norte compreende o conceito de empregabilidade "como reconhecimento do direito do indivíduo ao trabalho, à renda e à prática da cidadania que lhes garantam a dignidade enquanto seres humanos" (PEP-RN). Entende-se que esta compreensão difere das duas primeiras, e esta diferença só pode ser entendida quando se leva em conta o que o PEP-RN considera ser o papel da nova educação profissional. Segundo tal plano, no contexto atual, ela teria o dever de preparar o cidadão trabalhador para engajar-se de forma crítica em um mundo regido, principalmente, pelo conhecimento e pela mudança rápida e constante. Seria este o entendime nto de educação que levaria a uma outra compreensão de empregabilidade como um direito do indivíduo ao trabalho.

Entende-se que as duas primeiras acepções guardam correspondências com a definição da empre gabilidade-iniciativa, pois indiretamente estão sugerindo que o conjunto cumulativo de qualificações individuais, obtidas através da educação, possibilitaria a inserção e permanência do indivíduo no mercado de trabalho.

É certo que as transformações pelas quais o mercado de trabalho passou nas últimas décadas fizeram com que este começasse a exigir um trabalhador com um novo perfil profissional. A educação passou a ser também questionada no sentido de desenvol ver habilidades e competências nos indivíduos, a fim de que eles possam se inserir e se adaptar a este mercado em constante mutação. Entretanto, ao mesmo tempo em que estas novas exigências são feitas ao sistema educacional, a lógica acumulativa excludente do capitalismo impõe um processo de produção poupador de força de trabalho. O desemprego, seja conjuntural ou estrutural, ou sua ameaça, passa a ser uma constante. O trabalho informal cresce em proporção geométrica.

O MEC, ao se propor, a partir de 1997, a realizar a reforma da educação profissional, nas suas propostas para qualificação e requalificação da força de trabalho, incorporou o discurso de que a empre gabilidade estaria garantida se os indivíduos se submetessem a esses processos educativo s, seja os de forma inicial ou contínua. Entretanto,as estatísticas sobre emprego e desemprego no Brasil mostram tendência ascendente e indicam, com clareza, os limites das ações educacionais na superação ou redução do desempre go. O uso da noção de empre gabilidade adquire, assim, um conteúdoretórico, de pouco efeito prático, a não ser como discurso dissimulador das reais causas que alijam a força de trabalho do país do processo de construção do seu próprio desenvolvimento. 


\section{Empregabilidade e segurança no trabalho na política educacional do Ministério do Trabalho e Emprego}

O interesse aqui é observar qual noção de empre gabilidade se fez presente nos documentos do MTE que trataram das políticas públicas de trabalho, emprego e renda nos anos 90, mais especificamente as políticas direcionadas à educação profissional. Inicialmente, serão analisadas as noções de empregabilidade detectadas nos textos que tratam exclusivamente do Plano Nacional de Qualificação do Trabalhador (Planfor). Em seguida, as noções que tratam da educação profissional nos outros documentos mencionados anteriormente. Para isso, será levada em conta, principalmente, a categorização estabelecida por Gazier (2001).

A pesquisa documental possibilitou que se chegasse à conclusão de que as políticas de qualificação profissional executadas pelo MTE pautaram-se quase que exclusivamente na noção de empregabilidade política de mão-de-obra.

Esta noção de empregabilidade, conforme mencionado anteriormente, surgiu nos Estados Unidos, na década de 1960, em um período caracterizado por fortes discussões sobre os caminhos que deveriam seguir as ações que tinham como alvo o aumento da empregabilidade das populações desfavorecidas.

A empre gabilidade política de mão-de-obra foi definida por Gazier como a atratividade de um indivíduo aos olhos dos empregadores potenciais, ap reciado pelos resultados sintéticos de testes obtidos mediante a combinação da avaliação de aptidões e comportamentos e de sua capacidade de integração profissional.

Para o autor, o empre go desta noção de empre gabilidade destina-se a medir a distância entre as características de um indivíduo e os imperativos da produção e da aceitabilidade no mercado de trabalho. A operacionalização desta ve rsão de empregabilidade implica a ajuda a pessoas e grupos necessitados de obtenção e conservação de um emprego e a criação de planos de desenvolvimento de empregabilidade que envolvem ações de formação.

O surg imento do Planfor pode ser caracterizado, de certa forma, como uma tentativa de operacionalização da noção de empregabilidade política de mão-de-obra. Esta afirmação tem como base as seguintes constatações: 1) o Planfor 4 foi criado no âmbito do Ministério do Trabalho para atuar na formação, qualificação e requalificação da força de trabalho brasileira, a fim de que esta pudesse fazer frente às novas exigências que a reestruturação produtivaimpunha; 2) este plano tinha como objetivo reduzir o desemprego e o subempre go da PEA5; 3) a população-alvo nos programas que tiveram financiamento do Fundo de Amparo ao Trabalhador (FAT) foi, preferencialmente, composta por "pessoas mais vulneráveis econômica e socialmente, levando em conta a situação de pobreza, baixa escolaridade, idade, raça/cor, sexo, deficiências físicas e outros fatores de discriminação no mercado de 
trabalho" (MTb, 1999, p. 42); e 4) o plano se estabeleceu com o objetivo de:

“(...) construir, gradativamente, oferta de Educação Profissional - EP permanente, com foco na demanda do mercado de trabalho, de modo a qualificar ou requalificar, a cada ano, articulado à capacidade e competência existentes nessa área, pelo menos $20 \%$ da PEA (que soma, no Brasil, cerca de 71 milhões de trabalhadores ocupados no mercado formal e informal, além dos desocupados)" (MTb, 1999, p. 39).

Necessidades educacionais precisariam ser atendidas, uma vez que as deficiências neste sentido estariam freando o desenvolvimento do país. Entendeu-se que programas de formação poderiam possibilitar a integração e inserção das pessoas vulneráveis econômica e socialmente, as quais se encontravam em situação de risco.

À definição de empregabilidade política de mão-de-obra, está subjacente a idéia de 'desnível para o emprego regular', ou seja, o indivíduo não estava preparado para ser inserido no mercado, e de criação de mecanismos para melhorar a performance dos indivíduos no mercado de trabalho. Trata-se de uma versão centrada nas pessoas que se encontram em posição desfavorável. A concepção do Planfor e das políticas que foram desenvolvidas por ele tiveram como pano de fundo tais considerações.

Outros exemplos de utilização desta noção de empre gabilidade política de mão-de-obra pelo MTb puderam ser identificados. É o caso do documento Questões críticas da educação brasileira (Salm e Fogaça, 1995). Seus autores avaliam que hoje não é mais possível resolver o problema do emprego aberto no Brasil pelo crescimento da economia, uma vez que as mudanças que ocorreram na estrutura produtiva e na organização da produção alteraram a relação entre empre go e crescimento econômico. Consideram, assim, que isso teria levado a discussão sobre desempre go a enfatizar a noção de empre gabilidade, por eles considerada "como um mecanismo que daria aos segmentos mais vulneráveis da população trabalhadora as condições mínimas necessárias à obtenção de emprego" (Salm e Fogaça, 1995, p. 6).

Um segundo exemplo de re ferência à noção de empre gabilidade política de mão-de-obra pode ser observado no documento Sistema público de emprego e educação profissional: implementação de uma política integrada (MTb, 1996a), no item em que se expõe a nova proposta conceitual e metodológica para a área de qualificação profissional. De acordo com esse documento, a educaçãoprofissional' se situaria "como elemento de uma política pública de trabalho e renda, por sua vez integrada ao projeto mais amplo de modernização das relações capital-trabalho, consolidação da estabilidade econômica e conquista da equidade social no país" (MTb, 1996a, p. 5). Diz ainda que esta proposta teria ressaltado a necessidade de planos e projetos elabo- 
rados nos seguintes termos: "foco no mercado e na clientela, com vistas à empregabilidade dos treinandos (...) e abertura para novas clientelas, com prioridade para as populações em desvantagem social, ampliando assim o leque de atendimento antes restrito a desempregados" (p. 5).

Pela descrição da população a ser atendida, percebe-se que se trata da noção de empregabilidade política de mão-de-obra. Agora não só os desempre gados teriam este 'direito', mas também aqueles que estivessem em desvantagem social.

Em alguns dos documentos consultados, pôde-se perceber, ainda, que um mesmo texto ora tratava da empre gabilidade política de mão-de-obra, ora tratava da empregabilidade-iniciativa.

É o caso, por exemplo, da publicação do MTb (1998), Emprego no Brasil: diagnósticos e políticas, que tem por um de seus objetos as políticas de emprego. O MTb entende que a questão do emprego estaria representando um importante desafio para o governo federal, daí a grande importância da implementação de políticas voltadas para o fo mento do emprego, a educação, a qualificação e requalificação profissional, bem como para o desenvolvi mento de programas de proteção ao trabalhador. Assegura, também, que a questão do emprego exi ge ações governamentais de caráter normativo e programático e que estas se desdobrariam em políticas ativas e passivas.

Segundo este ministério, as políticas ativas se destinariam à promoção do emprego, ao aumento da empregabilidade da força de trabalho. Dentre elas, estariam as que teriam como objetivo a valorização da força de trabalho através dos investimentos em educação fundamental e da qualificação e requalificação profissional (MTb, 1998).

Quando o documento trata das ações governamentais de caráter ativo, que teriam o objetivo de promover a empregabilidade da força de trabalho por meio de inve s ti mentos em educação fundamental, de qualificação e requalificação profissional e de programas de proteção ao trabalhador, refere-se a populações em desvantagem social. É este o sentido presente na noção de empregabilidade política de mão-de-obra: o desenvolvimento de ações para minimizar a situação dos considerados deficientes sociais. Neste discurs 0,0 desenvolvimento da empre gabilidade é ap resentado como estratégia que garantiria a segurança do emprego.

O fato é que o sentido de empregabilidade política de mão-de-obra é mu ito próximo do sentido de empre gabilidade médico-social, em que as ações objetivavam a inserção dos portadores de deficiências físicas. Já na empregabilidade política de mão-de-obra, a atenção recai sobre os chamados deficientes sociais, os sem trabalho, os desempregados, os sem qualificação, que passam a compor, com os demais, os segmentos considerados vulneráveis da sociedade. Para atender a esta população, seriam, então, criados os progr amas de formação profissional, com a suposição de que eles poderiam contri- 
buir para a diminuição da distância entre as características dos indivíduos e os imperativos da produção, ou seja, pontos fracos dos indivíduos seriam trabalhados através de planos de desenvolvimento da empre gabilidade, a fim de assegurar-lhes a inclusão.

Outro termo que aparece nos documentos do MTE é a 'reconversão', principalmente quando reconhecem o descompasso existente entre a demanda e a oferta de mão-de-obra qualificada e quando se correlaciona esse fenômeno com o surgimento do desemprego estrutural. Busca-se, assim, enfatizar a necessidade de reconversão da mão-de-obra empregada em atividades decadentes, tendo em vista sua inserção em atividades emex pansão. A idéia de reconversão pode ser identificada tanto na noção de empre gabilidadeiniciativa quanto na noção de empregabilidade política de mão-de-obra.

O termo reconversão está relacionado à idéia de que podem existir 'muitos percursos profissionais' e que seria preciso dar atenção à formação continuada. No momento em que certas habilidades do indivíduo não mais se fizessem necessárias, ele deveria ime diata mente - atento ao mercado - se submeter a uma nova formação,que muitas vezes exigiria uma mudança radical do percurso profissional. Desta forma, a empre gabilidade estaria garantida caso os indivíduos se submetessem a este processo de reconversão.

Porém, nem sempre esta possibilidade pode ser desfrutada por um núme ro significativo de pessoas, pois isto exige ser capaz de antever a necessidade de uma nova formação que possibilite a reconversão. Isso se torna possível, por exemplo, quando existe a preocupação por parte dos emprega do res de fazer com que seus empregados conheçam os projetos de desenvolvimento da empresa, para poderem avaliar a necessidade de reconversão.

Entretanto, não são poucos os que constantemente se submetem a novos processos de formação e, mesmo assim, continuam desempregados. $\mathrm{O}$ discurso da empre gabilidade instala na mente dos indivíduos aquilo que Ferretti (2002) chama de insatisfação 'saudável' com o nível de aperfeiçoamento conseguido.

Para o MTb, empre gabilidade seria "atributo que o trabalhador deve possuir para aumentar a probabilidade de manter seu emprego ou de obter uma nova ocupação" (MTb, 1998, p. 43).

O termo 'atributo' contém a idéia de agre gação de valor, constante tanto da noção de empre gabilidade política de mão-de-obra quanto da noção de empregabilidade-iniciativa. A diferença é que, na primeira, programas seriam desenvolvidos com o objetivo de dotar a força de trabalho vulnerável econômica e socialmente destes atributos; já na segunda, os indivíduos teriam que, individualmente, anexar valores à sua força de trabalho para negociá-la no mercado de trabalho.

O que existe de comum nestas noções, no caso brasileiro, é que nelas está explícita ou implícita a responsabilização do indivíduo pelas saídas a serem 
encontradas no que diz respeito à geração de trabalho,emprego e renda, ou seja, pela realização do valor de troca de sua mercadoria, a força de trabalho.

Elementos da noção classificada por Gazier como empre gabilidade-iniciativa foram percebidos no documento produzido pelo $\mathrm{MTb}$, em parceria com o MEC, denominado Política para a educação profissional: cooperação (MTb e MEC, 1995). No item intitulado Premissas da politica de educação profissional, é colocado de forma explícita que a educação profissional deve ter como foco a empre gabilidade e que esta envolve três fatores inter-relacionados: investimentos geradores de trabalho, serviços de intemediação eficientes e educação continuada do trabalhador. Neste documento, a empre gabilidade foi então entendida como: “a capacidade não só de se obter um emprego, mas, sobretudo de se manter em um me rcado de trabalho em constante mutação, com características e natureza cada vez mais diferentes daquilo que se conhece, desde a re volução industrial até hoje" (MTb e MEC, 1995, p. 5).

Habilidades,uma questão de competências?7 (MTb, 1996b) constitui-se em outro documento no qual estão presentes as idéias de individualização e perspectiva otimista tão caras à noção de empregabilidade-iniciativa. Afirma-se que a implementação de habilidades básicas, específicas ou de gestão, asseguraria ao indivíduo desenvol ver com maior sucesso sua empre gabilidade: ele teria maior possibilidade de se manter empre gado, de se manter no mundo do trabalho.

Em primeiro lugar, destaca-se a visão determinista da relação entre educação profissional e empregabilidade. Em segundo lugar, está clara a responsabilização do indivíduo pelo sucesso na obtenção e manutenção de um emprego. Ao Estado caberia a execução de políticas para dotar a força de trabalho de habilidades e competências, mas ao indivíduo é transferida a responsabilidade pelo seu devir profissional. Esse processo de individualização é o elemento-chave que constitui a noção de empregabilidade-iniciativa.

A perspectiva otimista presente nesta versão de empre gabilidade obscurece a realidade do drama de um sem-núme ro de pessoas que estão em busca de emprego e não explica porque, entre os milhões de desempregados, encontram-se muitos que possuem escolarização elevada.

Para Frigotto (1998), o debate levado a efeito pelos 'homens de negócios' em torno do processo educativo e da qualificação humana, de repentina valorização do homem na condição de trabalhador, se materializa no esforço em atender às demandas da 'relação de poder político-econômico'. Trata-se, segundo o autor, da tentativa de rejuvenescimento da teoria do capital humano em conformidade com as orientações dos seus mentores: Banco Mundial, Banco Internacional de Desenvolvimento (BID), Organização das Nações Unidas para a Educação, a Ciência e a Cultura (Unesco), Organização Internacional do Trabalho (OIT) e seus parceiros nacionais e regionais. 
O direito de todo cidadão a uma educação de qualidade, que o possibilite transitar num mundo do trabalho cada dia mais complexo, não se confunde com as prédicas falaciosas sobre a inserção ocupacional como simples resultante de uma melhor qualificação ou do desenvolvimento de novas competências requeridas pelo mercado.

Um número significativo dos vários artigos produzidos pelo MTE foi elaborado pelo então responsável pela Secretaria de Formação e Desenvolvimento Profissional (Sefor) - atualmente Secretaria de Políticas Públicas de Emprego (SPPE) - , Nassim Gabriel Mehedeff, um dos principais divulgadores no âmbito do governo federal da noção de empregabilidade. Foram identificadas, no levantamento para esta pesquisa, mais de 14 entrevistas por ele concedidas no período de 1995 a 1997, nas quais informava sobre o Planfor e defendia a necessidade do desenvolvimento da empregabilidade da força de trabalho brasileira. O conjunto destas entrevistas, bem como outros artigos de sua autoria, encontra-se no documento Educação profissional no Brasil: conceitos e práticas em debate (Mehedeff, 1997a,1997b e 1997c).

Buscando a origem da noção de empre gabilidade, Mehedeff introduziu a versão de que ela foi lançada por especialistas emoutplacement8 para designar dispensa e recolocação de executivos e profissionais de nível superior. Explica que, neste contex to, a empregabilidade significava a posse de um "conjunto de conhecimentos, habilidades, comportamentos e relações que tornam o profissional necessário não apenas para uma, mas para toda e qualquer organização9" (Mehedeff, 1997a, p. 10).

Diz, ainda, que isto é válido para o trabalhador em qualquer nível e que, tão importante quanto ter um emprego, é tornar-se empregável e manter-se competitivo neste me rcado em constante mutação, onde, provavelmente, o indivíduo terá que se preparar para várias carreiras e diferentes trabalhos.

Para Mehedeff (1997a), a empre gabilidade compreende três ingre dientes fundamentais: competência profissional, disposição para aprender c o ntinuamente e capacidade de empreender. Com base nestes três ingredientes, o trabalhador estaria capacitado para fazer face às necessidades impostas pela reestruturação produtiva.

Ele entende que as competências seriam adquiridas através da formação contínua (disposição para aprender continu a mente). A capacidade de emp reender significaria ser portador de uma competência para desenvolver uma atividade autônoma, montar seu próprio negócio. Em se tratando da população a ser preferencialmente atendida pelo Planfor, certamente isso significaria um estímulo ao mercado informal, onde predominam relações de trabalho cada vez mais precarizadas.

Aliás, essas idéias vão bem ao encontro das formas de produção e reprodução da força de trabalho nos países subdesenvolvidos de que falam Mathias e Salama (1983). Dizem esses autores que, nos países subdesenvolvidos, a 
reprodução da força de trabalho não segue a mesma lógica dos países desenvolvidos. Eles justificam essa assertiva afirmando que a natureza de classe do Estado tem um fundamento diferente daquele estabelecido pelos países desenvolvidos e, desta forma, a força de trabalho se reproduz em parte no setor doméstico; mas, quando ocorre o desenvolvimento da industrialização e da urbanização, a reprodução da força de trabalho passa a estar vinculada ao desenvolvimento de um outro setor, o informal, que eles também chamam de "subterrâneo" (Mathias e Salama, 1983, p. 63).

As políticas de qualificação da força de trabalho colocadas em prática pelo governo brasileiro possibilitam, aos que se submetem a elas, que venham a desenvol ver atividades e se reproduzirem neste setor subterrâneo do qual os autores falam.

Mehedeff (1997a) diz, ainda, que a força de trabalho construída leva ndo em conta os três elementos apontados seria útil tanto para os setores de ponta como para a economia como um todo, pois os requisitos de produtividade, qualidade e competitividade deslizam por toda a cadeia produtiva, das grandes empresas aos seus terceirizados.

Esta parece ser uma questão a ser discutida. Talvez a exigência de uma maior qualificação seja um fato, mas não se pode concluir que a complexidade do conteúdo do trabalho tenha crescido na mesma proporção em todos os setores da economia. Há que se levar em consideração o nível de desenvo lvimento de cada região e até mesmo a divisão internacional e nacional do trabalho que estabelece papéis a serem cumpridos por cada região. Em se tratando da região Norte do Brasil, por exemplo, sabe-se que, historicamente, a ela foi dado o papel de fornecedora de matéria-prima. Isso faz com que nela seja desenvolvido um tipo de economia que demanda competências difere ntes dasexigidas, por exemplo, nas regiões onde indústrias de ponta se estabeleceram. Por outro lado, no caso das terceirizações, na grande maioria das vezes não existe a mínima chance de, neste tipo de contrato, serem estabelecidas relações de trabalho semelhantes às existentes nas grandes empresas.

Em relação à forma de contratação e salários, por exemplo, a pesquisa do Departamento Intersindical de Estatística e Estudos Socioeconômicos (Dieese) realizada nas seis principais regiões metropolitanas do país (Belo Horizonte, Distrito Federal, Porto Alegre, Recife, Salvador e São Paulo) mostra que, nos anos 90, houve dife renças de rendimentos entre os trabalhadores contratados na forma de 'contratação padrão' e os contratados na forma de 'contratação flexibilizada'10.

Os assalariados sem carteira assinada da região metropolitana de São Paulo tiveram um ganho real de 19,1\% naquela década. Por outro lado, aqueles com registro em carteira sofreram uma perda salarial de $14,2 \%$. Mas, segundo o órgão, quando os rendimentos das duas categorias são comparados, verifica-se que, em 1999, o salário médio do trabalhador com car- 
teira $(\mathrm{R} \$ 969,00)$ era cerca de $67 \%$ superior ao do empre gado sem registro (R\$ 581,00) (Dieese, 2001).

Verificou-se que os chamados autônomos (mas que trabalham para uma única empresa) tiveram queda de 33,1\% nas remunerações recebidas entre 1989 e 1999. O Dieese avalia que isto pode indicar uma mudança no perfil dos autônomos, pois:

\footnotetext{
“No início da década, o autônomo que trabalhava para a empresa (não para o público) talvez tivesse um perfil mais qualificado (consultores etc). Ao longo desses últimos anos, a contratação de autônomos por empresas parece ter se tornado uma forma disfarçada de as empresas substituírem mão-de-obra assalariada com registro em carteira, visando fugir do recolhi mentode encargos sociais e obterem maior flexibilidade e controle dos custos do trabalho" (Dieese, 2001, p. 92).
}

Quando Mehedeff (1997a) afirma que os requisitos de qualidade, competividade e produtividade deslizam por toda cadeia produtiva, esquece de mencionar as condições de trabalho dos terceirizados. No Brasil não acontece como na França, onde existe a idéia de que as empresas deveriam ser responsáveis pelo desenvolvimento da empregabilidade dos seus prestadores de serviço — os terceirizados.

Nos discursos presentes nos documentos consultados do MTE, encontram-se elementos que também re metem à noção de empre gabilidadeiniciativa. No entanto, a noção que realmente predominou foi a empregabilidade política-de-mão-de-obra. Isso se explica em razão da clientela a que o Planfor visava atender.

Continua dominante a ênfase na dimensão subjetiva que transfere para o sujeito a responsabilidade por sua inserção ocupacional. Argumenta-se que o mercado passaria por contínuas mudanças e que o trabalhador, para acompanhá-las, teria que se submeter a outras experiências de formação que possibilitassem o desenvolvimento de novas competências capazes de lhe abrir o caminho para uma diferente inserção.

Assegurando o processo de educação profissional continuada, a segurança no trabalho também estaria garantida. O MTE, ao propagar tais concepções, elege a noção de empre gabilidade como uma norma ideológica capaz de orientar condutas tanto no campo educativo como no campo das relações de trabalho.

\section{Empregabilidade e segurança no trabalho na política do Ministério da Saúde}

O MS também teve sob sua responsabilidade a tarefa de qualificar a força de trabalho. Para o desempenho de tal ação, desenvolveu o Profae. 
Sório analisa que:

“Ao longo do tempo, milhares de trabalhadores brasileiros não tiveram acesso à educação, tanto do ponto de vista geral quanto do profissional. Sem possibilidades de concluir seus estudos, ingressaram no mercado de trabalho em saúde como forma de sobrevivência. Dessa forma, os trabalhadores que atuaram e vêm atuando no processo produtivo em saúde, sem formação profissional e qualificação específicas para as funções que exercem, não vislumbram uma inserção digna nos planos de cargos e salários de suas instituições, não alimentam expectativas de crescimento funcional e muito menos obtêm registro profissional fornecido pelos órgãos de classe. Como resultado disso, esses trabalhadores têm sido marginalizados e tido baixo reconhecimento profissional e social" (Sório, 2002b, p. 47).

Nesta direção, a revista Formação informa que, em 1983, existiam 304.287 trabalhadores na área de enfermagem nos estabelecimentos de saúde do país, assim distribuídos: 25.889 enfermeiros, 19.935 técnicos de enfermagem, 64.289 auxiliares e 194.174 atendentes. Ainda segundo esta revista, em 1986, o mercado de trabalho do setor saúde absorvia cerca de $8 \%$ do total de empregos existentes na economia formal do país (MS, 2001).

De acordo com a revista, este foi um período em que o mercado de trabalho em saúde encontrava-se nitidamente em expansão e requisitava profissionais de todos os níveis de qualificação, sendo que o contingente mais solicitado era de pessoal de nível médio. Isto se atribuiu à variedade de funções no suporte aos diversos profissionais de nível superior.

Ocorreu, também em 1986, a aprovação da nova Lei de Exercício Profissional de Enfermagem ${ }^{11}$, que definiu apenas três categorias: enfermeiros, técnicos de enfermagem e auxiliares de enfermagem. Os atendentes, que representavam um núme ro significativa mente maior da força de trabalho nesta área, ficaram alijados desta classificação.

Foi ainda nesse período que os "estados e municípios, nos desdobramentos da crise do modelo médico assistencial privatista então vigente, passaram a assumir gradativamente a prestação dos serviços de saúde, desencadeando o processo que culminaria na criação do Sistema Único de Saúde - SUS" (MS, 2001, p. 8).

A avaliação foi que, a partir deste momento, a oferta de serviços de saúde por parte dos municípios ampliou-se,

“(...) uma vez que institucionalizada sua exclusividade na gestão local da saúde e, portanto, em última instância, sua responsabilidade política de prover saúde à população nos limites de seu território. Por outro lado, ao garantir a participação do setor privado, deu-se impulso ao crescimento de modalidades de prestação de serviços médicos e hospitalares vinculados a planos de saúde comercializados por 
empresas priva d as, cooperativas médicas, empresas de seguro saúde, e ao desenvolvimento de sistemas de autogestão de planos de saúde em empresas de grande porte. Em síntese, a oferta de empre gos no setor saúde teve que se ampliar para garantir a expansão da cobertura" (MS, 2001, p. 9).

Entretanto, o crescimento da demanda por pessoal de saúde não foi acompanhado pelo aparato formador e, neste cenário, o que se verificou foi o aumento do pessoal não-qualificado. Segundo entendimento presente no Projeto Larga Escala, o SUS, em seu período inicial de estruturação, procurou suprir a carência de formação de pessoal de nível médio através do desenvolvimento de processos de formação intramuros, em sua grande maioria patrocinados pelas próprias instituições e serviços de saúde públicos e priva dos.O setor público foi o mais bem-sucedido na oferta de cursos de formação de auxiliares, através da metodologia de educação em serviço (Projeto Larga Escala).

Foi também detectado que os empregadores da saúde, principalmente os do setor priva d o, começaram a dar pre ferência à contratação de pessoal com maior escolaridade. Os trabalhadores com menor grau de escolaridade eram cada vez mais preteridos. Segundo dados da Relação Anual de Informações Sociais (Rais) e Cadastro Geral de Empregados e Desempregados (Caged), do MTE, em 1986, 19.160 das pessoas admitidas no setor de serviços de saúde possuíam apenas a quarta série do ensino fundamental; em 1996, constata-se uma redução para 14.774. Enquanto isso, verificou-se um aumento na contratação de pessoas com o ensino médio: de 29.290, em 1986, para 84. 809, em 1996 (MS, 2001).

Mas não se pode deixar de considerar a existência de um grande contingente de trabalhadores da área da saúde à espera de qualificação. Entre as atendentes de enfermagem - que, segundo dados da Rais, totalizavam, em 1996, 115.686 pessoas — , 1,13\% eram analfabetas; 3,91\% possuíam a quarta série incompleta; $13,20 \%$, a quarta série completa; $17,03 \%$, a oitava série incompleta; e 28,69\%, a oitava série completa. Apenas 22,95\% deste contingente possuía o ensino médio completo (MS, 2001).

A pesquisa desenvolvida pelo Profae, intitulada "Avaliação do impacto da profissionalização dos trabalhadores da área de enfermagem na qualidade dos serviços de saúde", informa que, apesar de ter ocorrido um incremento na escolarização e profissionalização nas últimas décadas, dados da Rais e do Caged apontaram que, em 1998, 35\% dos trabalhadores da área de enfermagem não dispunham de qualificação técnica específica. O documento avalia que a presença deste contingente de trabalhadores sem formação p rofissional adequada acarretava riscos para a população e também a desvalorização do trabalho e do próprio trabalhador.

Diante desse cenário, o MS passou a implementar, a partir de 2000, o Profae ${ }^{12}$, cujo objetivo foi 
“qualificar esses trabalhadores que exercem sua profissão de forma irregular, diminuindo os riscos à população atendida e melhorando a qualidade da atenção hospitalar e ambulatorial, particularmente nos estabelecimentos integrantes do SUS" (MS, 2001, p. 9).

As principais metas estabelecidas pelo Profae foram: qualificação de 225 mil trabalha dores de enfermagem como auxiliares; promoção da escolarização de $25 \%$ da clientela que não havia concluído o ensino fundamental; capacitação de 12 mil enfermeiros como docentes da educação profissional em saúde; e modernização de 26 escolas técnicas de saúde do SUS (Sório, 2002a).

O projeto se propunha, também, a criar condições de continuidade e sustentabilidade aos programas de formação de nível médio para a saúde, de modo a impedir o surgimento, no futuro, de um novo contingente de trabalhadores em situação irregular.

Com esta iniciativa, o Profae buscava o aprimoramento da qualidade na área da saúde, pois

“graças a essa iniciativa do Ministério da Saúde, os profissionais habilitados, com um maior conhecimento de seu verdadeiro papel, terão oportunidade de contribuir com o seu trabalho para a melhor qualidade de todo o sistema de saúde" (MS, 2001, p. 3).

Por ser a população atingida pelo Pro fae constituída por trabalhadores da saúde, mais especificamente da área de enfermagem, com pouca ou nenhuma qualificação, a noção de empre gabilidade presente no programa, considerando-se a classificação de Gazier (2001), é a de empregabilidade política de mão-de-obra.

Entretanto, este programa ap resenta uma particularidade que permite afirmar que sua política se propôs a tratar da empregabilidade do pessoal da enfermagem à froid, como diriam os gestores de recursos humanos franceses.

Segundo estes gestores, quando o assunto empregabilidade é tratado em momentos em que o nível de desemprego torna-se agudo, tanto emprega dores como empregados estão lidando com uma situação muito difícil, daí empregarem o termo empregabilidade à chaud.

A empregabilidade tratada à froid vai exigir que tanto os empregadores como os empregados estejam jogando o mesmo jogo, que estejam fazendo avaliações contínuas e que, através destas, possam detectar as deficiências e buscar superá-las antes que se transformem em um obstáculo intransponível, ou seja, antes que elas impeçam a empregabilidade.

Diz-se que a grande diferença estabelecida pelo Profae com o seu programa de formação foi que a empre gabilidade dos trabalhadores, uma vez que a maioria destes se encontravam em situação de trabalho, foi tratada à 
froid, ou seja, antes que o problema da falta de qualificação se transformasse em desemprego irreversível ou em obstáculo para sua permanência no mercado de trabalho.Assim, o MS coloca em prática um projeto visando à mudança do perfil profissional dos trabalhadores já engajados no me rcado de trabalho, garantindo, dessa maneira, sua permanência neste mercado. E mais: propõe-se a desenvolver mecanismos que impossibilitem o surgimento, no futuro, de novos contingentes de trabalhadores em situação irregular. A proposta parece ser a educação continuada, ou formação ao longo da vida, que, neste caso, não deixa de ser uma forma de tratar a empregabilidade à froid.

Uma questão específica deste exemplo de tratamento à froid da empregabilidade diz respeito à preocupação com o atendimento. E isso ficou claro quando o Pro fae fez do exercício regular da profissão um de seus objetivo s, possibilitado pela oportunidade de melhoria da qualificação profissional e, conseqüentemente, o alcance da melhoria do atendimento e da diminuição dos riscos para a população atendida.

As avaliações realizadas por Bonfim e Torrez (2002), Pasqualin (2002), Sório (2002a) chamam a atenção para as conseqüências desta política para o re con he cimento profissional e social, além dos benefícios à população atendida por profissionais qualificados.

Na avaliação de Bonfim e Torrez (2002), a formação de trabalhadores sem qualificação, no contexto do Profae, teve as finalidades de proteger aqueles que precisavam de serviços de saúde, no sentido de garantir-lhes um atendimento sem riscos, e de gerar reconhecimento social e profissional daqueles trabalhadores.

Pasqualin (2002) avalia que os egressos dos cursos do Profae foram rapidamente absorvidos pelo mercado de trabalho e informa que os indicadores demonstraram que o 'nível de empregabilidade' destes egressos foi alto e que, conseqüentemente, um forte impacto na melhoria dos serviços de saúde pôde ser percebido.

Sório (2002a) comenta que o projeto se propôs a suprir certas deficiências originais da oferta de oportunidades do sistema de ensino profissional e do próprio ensino geral, as quais, combinadas à situação social e de gênero dos trabalhadores, produziram um efeito desastroso em termos de empregabilidade.

A autora também avalia que o tempo deveria ser visto como uma peçachave para a garantia de empre gabilidade, pois quanto mais rápido a qualificação dos milhares de trabalhadores fosse concluída, maiores seriam suas chances frente ao mercado de trabalho em saúde (Sório, 2002a).

Conclui-se, assim, que o MS fala de empre gabilidade, mas de forma um pouco mais implícita. Utiliza mais os termos qualificação, formação,profissionalização: qualificação de trabalhadores que exercem sua profissão de forma irregular, formação de trabalhadores sem qualificação, profissionalização intensiva dos trabalhadores em enfermagem etc. Entretan to, tudo isso 
em nome da manutenção no mercado dos trabalhadores que nele já se encontram, ou seja, de pessoas ativas. É exatamente este o diferencial: as ações teriam como foco as pessoas já engajadas.

Há um ponto em comum entre a noção de empre gabilidade política de mão-de-obra definida por Gazier e aquela executada pelo MS. Trata-se da clientela, que, nos dois casos, seria composta pelos necessitados, pelos vulneráveis social e economicamente. O ponto que afasta estas duas noções diz respeito à inserção: na empregabilidade política de mão-de-obra, políticas teriam que ser desenvolvidas não só para qualificar, mas também para inserir; já no caso da empre gabilidade política de mão-de-obra à froid, os indivíduos já estariam inseridos no mercado.

A comparação entre os ministérios da Educação, do Trabalho e Emprego e da Saúde em relação à apropriação e ao uso da noção de empregabilidade e aos sentidos que a ela atribuíram permitiu que se chegasse às conclusões apresentadas a seguir.

Tanto nos documentos do MEC como nos do MTE, as noções de empregabilidade utilizadas se aproximaram das ve rsões de empregabilidade-iniciativa e empregabilidade política de mão-de-obra.

A noção de empregabilidade-iniciativapredominou nos documentos do MEC, enquanto nos documentos do MTE a dominância foi da noção de empregabilidade política de mão-de-obra. Atribui-se este fato às diferenças quanto ao papel institucional destes dois ministérios.

Nos documentos do MS, a concepção de empre gabilidade que norteou as ações foi a empre gabilidade política de mão-de-obra, mas com o detalhe da execução à froid, já que as políticas desenvolvidas por este ministério tiveram como foco as pessoas ativas no mercado de trabalho e as ações de formação objetivaram a permanência delas no mercado. Complementando, o divisor de águas talvez seja o outro foco destas políticas: suas conseqüências em termos de benefícios diretos para os serviços de saúde, ou seja, a redução significativa dos riscos no atendimento.

O campo educacional, principalmente quando nas mãos do MEC e do MTE, constituiu-se em um dos principais campos de divulgação da noção de empregabilidade no Brasil, tendo por fio condutor as re formas pelas quais passou a educação profissional a partir de 1997, bem como os projetos desenvolvidos pelo MTE e os realizados em parceria com o MEC.

A noção de empre gabilidade esteve muito mais presente nos discursos do MTE do que nos discursos do MS e do MEC. Neste último, especificamente, foram encontrados com maior abundância e variedade termos correspondentes àquela noção.

Conforme já afirmamos, ela foi, sem dúvida, importada e os organismos transnacionais contribuíram para isso, mas aqui encontrou ressonância e propagadores. 
No MEC, assim como no MTE, os responsáveis pela divulgação da noção de empre gabilidade de alguma forma tinham ou tiveram vínculos com organismos transnacionais, difusores dessa noção.

\section{Conclusões}

A busca da gênese da noção de empre gabilidade e o conhecimento dos significados assumidos por esta noção nas últimas décadas permitiram que se concluísse que sua utilização sempre esteve ligada à necessidade de se justificar um problema que se tornou uma constante tanto nos países de cap italismo avançado como nos países de capitalismo periférico: o desemprego.

Verificou-se que tanto os sentidos quanto os usos da noção de empregabilidade podem ser mais bem explicitados quando é feita sua contextualização e quando se utilizam algumas categorias analíticas. Para tanto, os conceitos de valor de uso e de valor de troca são de grande valia.

Se a força de trabalho é uma mercadoria, tal como as outras ela pode ser compreendida como valor de uso e comovalor. Marx $(1989$, p. 55) diz que as mercadorias só são assim consideradas "por sua duplicidade, por serem ao mesmo tempo objetos úteis e veículo de valor. Por isso patenteiam-se como mercadorias, assumem a feição de mercadoria, apenas na medida em que possuam dupla forma, aquela natural e a de valor". Marx considera, também, que é exatamente a utilidade de uma coisa que faz dela um valor de uso e que o valor de uso só se realizará com a utilização ou o consumo da mercadoria.

Quando se consideram os vários sentidos atribuídos à noção de empregabilidade nas últimas décadas, o que se pode concluir é que, quase sempre, eles re metem à necessidade de utilização da força de trabalho, ou seja, é a visão utilitarista e pragmática que pre valece. Excetuando-se as noções de empre gabilidade dicotômica, empre gabilidade-fluxo e empre gabilidade performance sobre o mercado de trabalho, todos os outros sentidos atribuídos a este termo, explícita ou implicitamente, apre goam a necessidade de aperfeiçoamento e formação continuada do indivíduo.

A investigação mostrou que os sentidos atribuídos à noção de empregabilidade pelo governo federal deram-se por intermédio dos ministérios que se destacaram no desenvolvimento de políticas de formação da força de trabalho. A identificação destes sentidos, mediante o exame dos discursos produzidos por esses ministérios, possibilitou que se percebesse que o termo passou a fazer parte dos discursos que ap regoavam a necessidade da reforma do ensino, particularmente da educação profissional.

Observa-se que esta noção começa a ap a recer com mais freqüência no discursoeducacional a partir da segunda metade da década de 1990 - período em que foi registrada uma queda no nível absoluto do emprego assalaria- 
do estruturado. Um dos arg umentos utilizados foi que o desemprego era conseqüência da inadequação da força de trabalho, em termos de habilidades e competências, às exigências do mercado. Seria necessário, então, que a força de trabalho fosse submetida a programas contínuos de qualificação e requalificação, pois só assim a empregabilidade poderia ser assegurada. Este foi o terreno fecundo para que a noção de empregabilidade se institucionalizasse.

O governo federal passou, então, a utilizar, nos discursos justificadores da necessidade de qualificação, basicamente duas ve rsões de empregabilidade: a empregabilidade política de mão-de-obra e a empregabilidade-iniciativa.

A noção da empre gabilidade política de mão-de-obra predominou nas propostas de formação profissional ap resentadas pelos ministérios do Trabalho e Empre go e da Saúde, sendo as características ap resentadas pela clientela-alvoum dos fatores que identificam o sentido adotado por esta noção. Nos documentos do MEC, a ve rsão de empregabilidade-iniciativapredominou, muito embora, em alguns momentos, a presença da versão política de mão-de-obra tenha sido observada.

Assim, os poderes instituídos - a começar pelo nível federal — passaram a utilizar a noção de empre gabilidade como uma justificativa para a não-inclusão, ou seja, para o não-sucesso dos indivíduos nas suas tentativas de inserção ocupacional. Dessa forma, aqueles que quisessem garantir a inserção no mercado de trabalho deveriam desenvolver sua empre gabilidade. Caberia tão somente ao sistema educacional a responsabilidade pela oferta de meios para que os indivíduos obtivessem um lugar no mercado e estes teriam a responsabilidade pelas saídas a serem encontradas.

A individualização passa a ser, assim, um dos elementos-chave da noção da empregabilidade, ou melhor, a noção de empregabilidade passou a assentar-se em um entendimento de individualização que, em um prime i ro momento, significa a desincorporação dos modos de vida da sociedade industrial. Posteriormente, ela passa a significar a incorporação de novas formas de viver a vida, de tal sorte que os indivíduos devem produzir, representar e acomodar suas próprias biografias. É esta a idéia presente quando o discurso da empre gabilidade apregoa a necessidade da construção dos vários itinerários profissionais marcados pela adaptabilidade e pela flexibilidade. Esta individualização supõe, portanto, a responsabilização dos indivíduos por suas trajetórias pessoais no campo da vida profissional. Uma vida profissional calcada na incerteza e no 'correr riscos', bem como em novas maneiras de organizar o tempo — sobretudo o tempo de trabalho — , uma vez que agora a carreira tradicional tecida, quando muito, em uma ou duas empresas desapareceu, sendo substituída por 'projetos' e 'campos de trabalho'.

Sennett (2004, p. 12) diz que, "hoje, um jovem americano com pelo menos dois anos de faculdade pode esperar mudar de emprego pelomenos onze vezes no curso do trabalho, e trocar de aptidão básica pelo menos ou- 
tras três durante os quarenta anos de trabalho". No Brasil, pode-se dizer que poucos serão aqueles que conseguirão acessar o me rcado de trabalho formal. Quando muito conseguirão desenvolver atividades em um mercado informal marcado por uma precarização crescente. O processo de produção e re produção da força de trabalho em nosso país não segue a mesma lógica dos países desenvolvidos.

Para Mathias e Salama (1983), isso ocorre por conta da natureza de classe do Estado, que tem um fundamento diferente daquele estabelecido pelos países desenvolvidos. Desta forma, conforme apresentado anteriormente, entendem que a força de trabalho nos países subdesenvolvidos se reproduz no setor doméstico, mas, quando ocorre o desenvolvimento da industrialização e da urbanização, a reprodução da força de trabalho passa a estar vinculada ao desenvolvimento de um setor que é chamado de informal e, também, de subterrâneo. Esta lógica possibilita entender a existência do discurso queresponsabiliza o indivíduo por sua trajetória profissional baseada na flexibilidade e na idéia do indivíduo empreendedor, que não precisa da tutela do Estado para construir esta trajetória. Dada a incapacidade da economia para criar emprego s, estas trajetórias seriam construídas, obviamente, no setor dito informal.

Entende-se que o discurso presente nos documentos norteadores das políticas de educação profissional pode ser visto como uma estratégia que objetivou o conven cimento da força de trabalho de que o desenvolvimento da empregabilidade seria o passaporte para a segurança no trabalho.

Mas como acreditar na possibilidade de obtenção da segurança no trabalho alentada por estes discursos oficiais se o nível de desemprego nas seis principais áreas me tropolitanas do Brasil ap resentou um crescimento acumulado de 30,6\% no período de janeiro a outubro de 2003; se a taxa de desemprego saltou de 10,5\% em dezembro de 2002 para o patamar de 12,9\% em outubro de 2003; se a taxa de desemprego para a população sem instrução ou com até três anos de estudo ficou em 5,4\% e em 6,4\% para aqueles com mais de oito anos de escolaridade em 2002 (MTE, 2003)?

Mesmo com estes dados que ex pressam a realidade, percebe-se que a instância ideológica funciona através do assujeitamento do sujeito ideológico, levando-o a se perceber como senhor de sua própria vontade, gestor e negociador da sua força de trabalho. Se não tiver sucesso nesta empreita da, a culpa é somente sua, já que não soube negociar e gerenciar o único bem que possui: a sua força de trabalho.

Paradoxalmente, quanto mais se recrudesce a crise do desemprego e do trabalho informal e inseguro, mais a utilização de noções - como a de empre gabilidade - ganha espaço ideológico, mitificando as condições de superação desta adversidade por não levar em conta seus fatores objetivos e tra $\mathrm{n}$ s ferir as possibilidades de seu equacionamento para o campo das subjetividades humanas. 
Por outro lado, o impacto positivo sobre o emprego a partir da melhoria das chamadas condições de empregabilidade da força de trabalho não chegou a ser verdadeiramente comprovado. Na realidade, o problema deriva de modelos de desenvolvimento econômico, de alternativas que possam levar à criação de empregos pelas atividades produtivas.

O uso político-ideológico da noção de empregabilidade fez com que fossem estimuladas e implementadas novas normas de abordagem e de comport amento nos processos educativos e nas relações de trabalho. Estas dizem re speito, por exemplo, às novas competências que deveriam ser desenvolvidas. Dizem respeito,também, à construção de um novo indivíduo, de outro perf i 1 profissional. Arg u mentam que o mercado precisa de uma força de trabalho que saiba aprender e empreender, absolutamente flexível, que saiba se antecipar ao futuro e agregar valor a si mesma, de modo a tornar-se uma merc adoria atrativa ao futuro empregador e vir a se realizar como valor de troca.

Marx considera que a força de trabalho (assim como outras mercadorias) possui uma grandeza que pode ser medida "por meio da quantidade da 'substância criadora de valor' nele contida, o trabalho13" (Marx, 1974, p. 45). A quantidade de trabalho, por sua vez, mede-se pelo tempo de sua duração e o tempo de trabalho, por frações do tempo, como horas, dias etc. Mas, às vezes, o que ocorre com a me rcadoria força de trabalho é diferente daquilo que acontece com os outros tipos de mercadorias, pois, mesmo se transformando em uma grandeza de valor - uma vez que nela está contida uma quantidade ou um tempo de trabalho socialmente necessário para a p rodução de um valor de uso - , a me rcadoria força de trabalho pode não se transformar em valor de uso quando da não-existência de uma demanda efetiva por ela. Desta forma, o valor de troca não se concretiza.

Ainda segundo este autor, "o produto para se tornar mercadoria tem de ser transferido a quem vai servir como valor de uso por meio de troca" (Marx, 1974, p. 45). Mas como efetivar o valor de troca da mercadoria força de trabalho em um mercado cada vez mais restrito? Mesmo quando a formação profissional é estimulada, quando se incentiva tornar mais sofisticada e mais qualificada uma determinada força de trabalho, dadas às condições econômicas do país, quando não se pratica uma política de emprego e geração de renda realmente séria, deduz-se que, provavelmente, os possuidores destas quantidades de trabalho social não serão vistos, senão por eles me smos, como mercadorias. Para o mercado, eles serão vistos tão-somente como 'valor', já que não se efe ti vam como objetos úteis. Certamente esta força de trabalho mais sofisticada vai significar que uma maior quantidade de trabalho ou tempo socialmente necessário foi utilizado em sua produção, sem que isso resulte na possibilidade do valor de troca ser efetivado.

No cenário econômico atual, as relações de trabalho passam a ser consideradas voláteis e a mobilidade dos trabalhadores se torna um imperativo, 
uma vez que se considera que o tempo das carreiras profissionais contínuas e das qualificações duráveis teria acabado.

É neste cenário que podem ser percebidas as novas formas, os novos mecanismos de valorização da força de trabalho. Agora não basta apenas um conjunto de qualificações que valeria durante toda a vida produtiva. Exigese, hoje, o ap render sempre. E as competências exigidas mudam a cada momento, compondo um quadro de permanente instabilidade.

Percebe-se, ainda, na discussão sobre empregabilidade, a resignação em relação à idéia de que o contrato de trabalho formal e de longo prazo tornou-se uma realidade distante. Há o entendimento de que o novo modo de contrato - 'por tare fas' ou 'por projetos' — seria a modalidade de relação de trabalho a predominar. Neste sentido, o indivíduo poderia ter, ao mesmo tempo, vários ou nenhum empregador. Suas chances passariam a depender tanto do capital humano como do capital social que conseguiu construir. Sendo assim, também ele (um 'capitalista') deveria se guiar pela lógica da acumulação de capitais. A noção de empre gabilidade, ao ganhar este sentido, se presta, sem dúvida, a endossar ideologicamente padrões de pensamento e de conduta, de políticas e de relações sociais que são expressões deste tempo de crise social profunda. 


\section{Notas}

1 Professora do Centro de Filosofia e Ciências Humanas da Unive rsidade Federal do Pará. Doutora em Educação pela Universidade Federal de Minas Gerais. < angelicaalberto@hotmail.com>

2 Segundo Sennett (2004), a palavra 'flexibilidade' entrou na língua inglesa no século XV. Para o autor, o sentido do termo derivou, originalmente, da simples observação de que, apesar da árvore se dobrar ao vento, seus galhos sempre voltam à posição inicial. Flexibilidade designaria, assim, a capacidade da árvore de ceder e se recuperar, o teste e arestauração de sua forma. Neste sentido, o comportamento humano flexível teria a mesma força tênsil: ser adaptável a circunstâncias variáve i s, mas não 'quebrado' por elas. O autor indaga se haveria limites, até onde as pessoas seriam obrigadas a dobrar-se, e se poderia o governo dar às pessoas alguma coisa semelhante à força tênsil de uma árvo re, para que elas não se partam sob a força da mudança.

3 Segundo Dolabela (1999), nos Estados Unidos, o núme ro de instituições univers itárias que ofe recem este tipo de conteúdo passou de 50, em 1975, para mais de mil, em 1988. Em cinco estados daquele país, o ensino de empreendedorismo seria obrigatório.

4 O Planfor assume importância estratégica na política de emprego e renda do governo Fernando Henrique Cardoso (1995-2002). O desempre go, para as análises oficiais, teria origem na baixa qualificação da mão-de-obra, insuficiente para atender às demandas da chamada reestruturação produtiva. Em outras palavras, para o governo, o fenômeno do desemprego resultava do desajuste entre uma economia que cresceu e se modernizou e o baixo nível de qualificação profissional da PEA, inábil para atender às demandas do novo contexto produtivo.

5 Segundo dados do MTE, a PEA brasileira não atinge, em média, quatro anos de estudo (não necessariamente de escolaridade) e abriga $20 \%$ de analfabetos declarados ou funcionais.

6 Para o MTE, embora a educação profissional por si só não crie empregos, é um componente essencial da empregabilidade de jovens e adultos.

7 O documento Habilidades, uma questão de competências é uma simulação de reunião onde os participantes têm como objetivo discutir e explicitar as principais dúvidas acerca do tema.

8 Outplacement é uma técnica de gestão de re cursos humanos que visa apoiar os trabalhadores dispensados rumo à busca de sua reinserção profissional. As consultorias em outplacement fornecem aconselhamento financeiro e formação em recrutamento e seleção. Há empresas que prefe rem criar centros de outplacement internos, para prestar auxílio aos trabalhadores dispensados e aos que são recolocados em novas funções.

9 Para Mehedeff (1997b), hoje, mais importante do que apenas obter um emprego é manter-se empregável, manter-se competitivo em um me rcado em mu tação. Segundo ele, o profissional deve, inclusive, se preparar para várias carreiras e diferentes trabalhos.

10 O Dieese define como contratação flexibilizada aquela caracterizada pelo empre go de trabalhadores semregistro na carteira profissional, pelo uso de empre gados contratados 
em serviços terceirizados e pela prestação autônoma de serviços a uma única empresa. A contratação padrão seria aquela feita pela empresa mediante assinatura da carteira de trabalho do empregado (Dieese, 2001).

11 Esta lei veio estabelecer responsabilidades aos profissionais de enfermagem. A responsabilidade técnica por todas as ações de enfermagem ficou a cargo dos enfermeiros. Aos técnicos e auxiliares de enferma gem coube o desenvolvimento de atividades proporcionalmente menos complexas, de acordo com o seu grau de escolaridade formal. Ficou também estabelecido que os atendentes de enfermagem, entãoregularmente empregados, deveriam se qu alificar formalmente como auxiliares de enfermagem em um prazo de dez anos (MS, 2001).

12 O Profae "está estruturado em dois componentes, que expressam duas linhas de atuação: redução do déficit de pessoal auxiliar de enfermagem qualificado para atuar no setor, e reforço do quadro normativo e de regulação na área de saúde, com a criação de condições técnico-financeiras para continuidades dos processos de formação técnica em saúde, em especial de pessoal auxiliar de enfermagem" (MS, 2001, p. 7).

13 Marx considera que os valores de troca das mercadorias são apenas funções sociais que nada têm a ver com suas qualidades naturais, e o que se deve saber é que a 'substância social' comum a todas as mercadorias é o 'trabalho'. 


\section{Referências}

BONFIM, Maria Inês do R.; TORREZ, Milta Neide F. B. 2002. A formação do formador no Pro fae: refletindo sobre uma p roposta na área de enfermagem. Formação, v. 2, n. 4., p. 15-34.

CASTRO, Janete L. de (org.). 2002. Profae: educação profissional em saúde e cidadania. Brasília: Ministério da Saúde.

DIEESE (Departamento Intersindical de Estatística e Estudos Sócio-Econômicos). 2001. A situação do trabalho no Brasil. São Paulo: Dieese.

DOLABELA, Fernando. 1999. Oficina do empreendedor. São Paulo: Cultura Editores Associados.

FERRETTI, Celso João. 2002. Empresários, trabalhadores e educadores: diferentes olhares sobre as relações trabalho e educação no Brasil nos anos recentes. In: LOMBARDI, José Claudinei et al. (org s.). Capitalismo, trabalho e educação. Campinas: Autores Associados, p. 97-142.

FRIGOTTO, Gaudêncio. 1998. A educação e a formação técnico-profissional frente à globalização excludente e o desemprego estrutural. In: SILVA, Luiz H. (org.). A escola cidadã no contexto da globalização. Petrópolis: Vozes, p. 218-238.

GAZIER, Bernard. 2001. L'employabilité. Paris. (Mimeo).

MACHADO, Lucília Regina de S. 1998. Educação básica, empregabilidade e competência. Trabalho \& Educação, n. 3, p. 15-31.

MARX, Karl. 1974. Trabalho assalariado e capital: salário, preço e lucro. Porto: Publicações Escorpião. 1989. O capital. Livro I. Volume I. $13^{\text {a }}$ ed. Rio de Janeiro: Bertrand Brasil.

MATHIAS, Gilberto; SALAMA, Pierre. 1983. O Estado superdesenvolvido: ensaios sobre a intervenção estatal e so$\mathrm{b}$ re as formas de dominação no capitalismo contemporâneo. São Paulo: Brasiliense.

MATOSO, Jorge Eduardo L. 1998. Transformações econômicas recentes e mudanças no mundo do trabalho. In: OLIVEI-
RA, Marco Antônio de (org.). Economia e trabalho: textos básicos. Campinas: Unicamp, p. 61-77.

MEC (Ministério da Educação). 1998. Resolução no 3, de 26 de junho de 1998. Institui as Diretrizes Curriculares Nacionais para o Ensino Médio.

2001a. Lei Federal no. 9.394/96. In: Educação profi s s i o n a l: legislação bás i c a . Brasília: Programa de Expansão da Ed ucação Profissional, Secretaria de Educação Média e Tecnológica, p. 17-48.

2001 b. Decreto Federal no. 2.208/97. In: Educação profissional: legislação básica. Brasília: Programa de Expansão da Educação Profissional, Secretaria de Ed ucação Média e Tecnológica, p. 51-54. 2001c. Parecer CNE/CEB no. 16/99. In: Educação profissional: legislação básica. Brasília: Programa de Expansão da Educação Profissional, Secretaria de Educação Média e Tecnológica, p. 99-139.

Secretaria de Educação Média e Tecnológica. 2002. Programa Técnico Empreendedor. Disponível em: <www.mec.gov.br/semtec/redefederal/tecempreend.htm>. Acesso em: 14 jun. 2003.

MEHEDFF, Nassim Gabriel. 1997a. Do "operário padrão" ao cidadão produtivo: o desafio de educar para a empre gabilidade. In: MTb. Educação profissional no Brasil: conceitos e práticas em debate. Brasília: Secretaria de Formação e Desenvolvimento Profissional, Ministério do Trabalho,p. 10-12.

1997b. O emprego em transformação. In: MTb. Educação profissional no Brasil: conceitos e práticas em debate. Brasília: Secretaria de Formação e Desenvolv i mento Profissional, Ministério do Tr abalho, p. $20-23$.

1997c. A era da empre gabilidade. In: MTb. Educação profissional no Brasil: conceitos e práticas em debate. Brasília: Secretaria de Formação e Desenvolvimento Profissional, Ministério do Tr abalho, p. 17.

MS (Ministério da Saúde). 2001. Oferta de qualificação é necessária paramelhorar 
a atenção à saúde. Formação, v. 1, n. 1, p. 7-12.

MTb (Ministério do Trabalho). 1996a. Sistema público de emprego e educação profissional: implementação de uma política integrada. Brasília: Secretaria de Formação e Desenvolvimento Profissional. 1996b. Habilidades, questão de competências? Brasília: Secretaria de Formação e Desenvolvimento Profissional, MTb/Conselho Deliberativo, Fundo de Amparo ao Trabalhador.

1998. Emprego no Brasil: diagnóstico e políticas. Brasília: Assessoria Especial do Ministro.

1999. Educação profissional:um projeto para o desenvolvimento sustentado. Brasília: Secretaria de Formação e Desenvolvimento Profissional, MTb/Conselho Deliberativo, Fundo de Amparo ao Trabalhador.

; MEC (Ministério da Educação). 1995.

Politica para a educação profissional e cooperação MEC/MTb. Brasília: MEC/MTb.

MTE (Ministério do Trabalho e Emprego). 2003. Notas sobre o mercado de trabalho em 2003. Disponível em: <internet/EstudiososPesquisadores/ observatorio/indicadores/Conteudo/ Nota_sobre_o_MT_em_2003.pdf $>$. Acesso em: 12 jan. 2004.
PASQUALIN, Marli A. J. 2002. Centro Formador de Recursos Humanos Caetano Munhoz da Rocha - Secretaria de Estado da Saúde do Paraná. Formação, v. 2, n. 5, p. 93-100.

POCHMANN, Márcio. 2000. Emprego e trabalho no Brasil em perspectiva. In: RATTNER, Henrique (org.). Brasil no limiar do século XXI: alternativas para a construção de uma sociedade sustentável. São Paulo: Edusp, p. 125-137.

SALM, Cláudio; FOGAÇA, Azuete. 1995. Questões críticas da educação brasileira. Brasília: MCT-Pacti/Mict-PBQP.

SENNETT, Richard. 2004. A corrosão do caráter: conseqüências pessoais do trabalho no novo capitalismo. $8^{\mathrm{a}}$ ed. Rio de Janeiro: Record.

SÓRIO, Rita E. da R. 2002a. Inovações no campo da gestão de projetos sociais: uma reflexão à luz da experiência do Profae. In: CASTRO, Janete L. (org.). Profae: educação profissional em saúde e cidadania. Brasília: Ministério da Saúde, p. 17-29.

. 2002b. Educação profissional em saúde no Brasil: a proposta das escolas técnicas de saúde do Sistema Único de Saúde. Formação,v. 2, n. 5, p. 45-58.

Recebido em 04/11/2004

Aprovado em 10/02/2005 